${ }^{\odot}$ Entomologica Fennica. 3 July 2002

\title{
The phenology of dominant scuttle-fly (Diptera: Phoridae) species in the Białowieża Forest
}

\section{Ewa Durska}

Durska, E. 2002: The phenology of dominant scuttle-fly (Diptera: Phoridae) species in the Białowieża Forest. — Entomol. Fennica 13: 123-127.

Scuttle flies were collected in different-aged pine stands in 1986 and 1987, using yellow plastic bowls attached to crowns of trees or placed on the ground. The phenology of Megaselia brevicostalis, $M$. giraudii and $M$. verralli, the dominant species of moist pine forest in the Białowieża Forest, was characterized by two or more abundance peaks, which indicate a multivoltine life cycle. Megaselia diversa, the autumn eudominant of young-growth phase stands, and Megaselia woodi, the autumn dominant and eudominant of the stands of older age classes, are both univoltine species. Their abundances peaked in September. Along the increasing age of the stands, distinct successional phases of phorid communities were recorded: photophilous species of open sites ( $M$. brevicostalis and $M$. verralli) were replaced by forest species $(M$. diversa, $M$. giraudii and $M$. woodi).

Ewa Durska, Museum and Institute of Zoology, PAS, Wilcza 64, 00-679 Warszawa,Poland; E-mail: edurska@miiz.waw.pl

Received 7 September 2001, accepted 5 December 2001

\section{Introduction}

The Phoridae are one of the most abundant families of Diptera in woodland, meadow, agroecosystem and urban habitats, albeit one of the least studied. To date, about 3000 species have been described, and one-fourth of these occur in the Palaearctic Region.

Detailed studies of seasonal fluctuations in the number of adult scuttle flies are lacking for most species. Most species tend to be bivoltine at lower altitudes and univoltine at higher altitudes (Disney et al. 1981).

Differences in climate may affect phenology of Phoridae, because scuttle flies are very sensitive to microclimatic changes or habitat alteration (Durska 1996, Durska 2001). During a drought year, the spring peak of emergence may appear earlier and may have a different course than in "average" years. A low spring peak of emergence usually precedes a high autumn peak. Humidity is the most important factor limiting the abundance of Phoridae; consequently, in a drought year the abundance is often severely reduced, even by $90 \%$ (Disney et al. 1981).

This paper supplements an earlier paper on secondary succession of scuttle-fly communities in moist pine (Pinus sylvestris) forests in the Białowieża Forest, and refers to the dominant species in four age classes (Durska 2001).

\section{Study area}

In Poland, the secondary succession of a moist pine forest lasts 120-150 years (pine plantation 


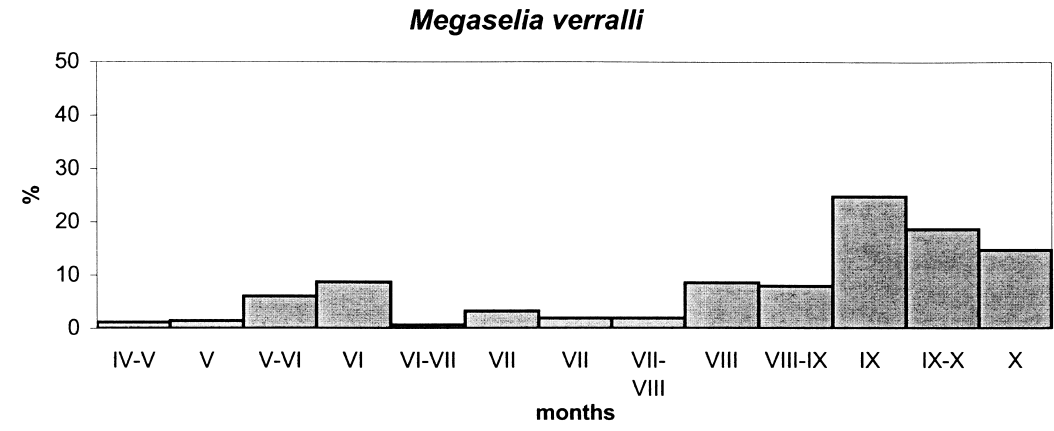

Fig. 1. The phenology of Megaselia verralli in moist pine stands in the Białowieża Forest (age classes combined). or culture, young-growth, small pole timber, large pole timber and mature or old-growth stand) (Szujecki 1980).

The studies concerning the secondary succession of scuttle flies in the Białowieża Forest were carried out in the forest of the Starzyna Division (District Hajnówka). Three areas were selected in the following divisions: 538 (Ba, Bc, Bd, Bf), 634 (Bc, Ef), $667 \mathrm{Bf}$ and $668\left(\mathrm{Ad}_{2}, \mathrm{Af}_{1}, \mathrm{Cc}\right)$. At each of these areas, several-hectare, even-aged forest plots were chosen: pine plantation (the age of the saplings 4-8 years), young-growth (the age of the trees 16-22 years), large pole timber (ageclass III; the age of the trees 50 years) and oldgrowth (the age of the trees 140-145 years) stand. The soil and phytosociology of the selected stands were homogeneous for a human eye. The study areas represent the sub-boreal variety of the Peucedano-Pinetum association (Matuszkiewicz et al. 1993).

\section{Material and methods}

The phorid material was collected in 1986-1987, using yellow plastic bowls (diameter ca. $18 \mathrm{~cm}$ ) with $75 \%$ ethylene glycol and detergent. The traps were attached to crowns of pines or, in pine plantations, placed on the ground. The trapping lasted from April to October. The traps were emptied, in general, every fortnight. The method, first employed by Moericke (1950) to catch aphids and later modified by J. Sawoniewicz, was used in zoocoenological studies to collect all insects living in tree canopies (Bańkowska \& Garbarczyk 1981). For the scuttle flies, the "yellow trap" method allows the most complete sampling, not only from tree canopies and from shrubs but from understory foliage as well. Unlike other collecting techniques such as sweepnetting, beating or light-trapping, the method employed gives a relatively unbiased picture of the phorid community structure, where Megaselia is the most diverse and the most abundant genus (about $70 \%$ of all known phorid species) (Disney 1994). Continuous trapping ensures the catchability of different diurnal activities of species, and monitors their seasonal fluctuations.

Five traps, one per tree, were placed in each plot. Altogether 60 traps were run in the four age-classes. The material contained 57181 phorid imagines. Of these, $9 \%$ were caught in pine plantation, $37.2 \%$ in young-growth, $27.4 \%$ in large-pole timber and $26.4 \%$ in old-growth stands.

The abundance of a particular species was calculated as $100 \times n$, where $n$ is the mean number of individuals collected per bowl during a 24-hour period. Factor 100 was used to obtain higher numerical values of the abundance index.

The number of species and their abundance, as reported in this paper, represent mean values obtained during the two study seasons.

To describe the dominance structure of communities, a dominance index (D) was used (Durska 2001):

$$
D=n / N \times 100 \%
$$

where $n=$ the abundance of a given species, and $N=$ the accumulated abundance of all phorid species.

The dominance index $(D)$ was used to classify the species into four classes: (1) eudominants (over 15.0\%), (2) dominants (from $5.1 \%$ to $15.0 \%$ ), subdominants (from $1.1 \%$ to $5.0 \%$ ) and (4) accessory species (up to $1.0 \%$ ).

\section{Results}

The majority of the species reached their abundance peaks in spring (May; the lower peak) and in autumn (September; the higher peak), as earlier suggested by Durska (1996, 2001). Megaselia verralli (Wood) and M. brevicostalis (Wood) were the eudominant species of pine plantations, their total catches forming $22.5 \%$ and $15.1 \%$ of the total catch, respectively.

The first $M$. verralli individuals were recorded at the turn of April and May. The spring peak 


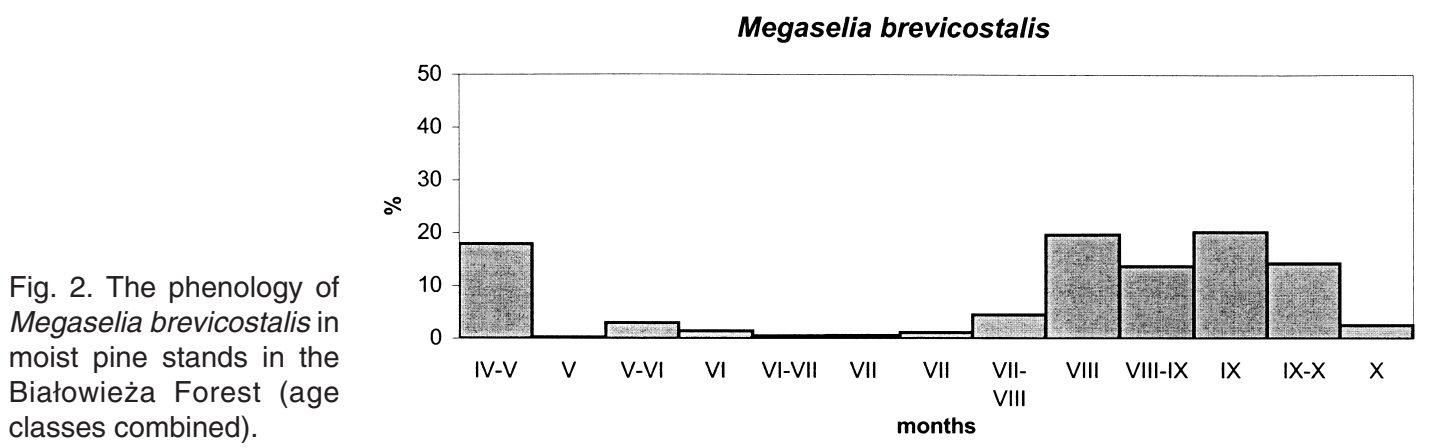

Fig. 3. The phenology of Megaselia diversa in moist pine stands in the Białowieża Forest (age classes combined).

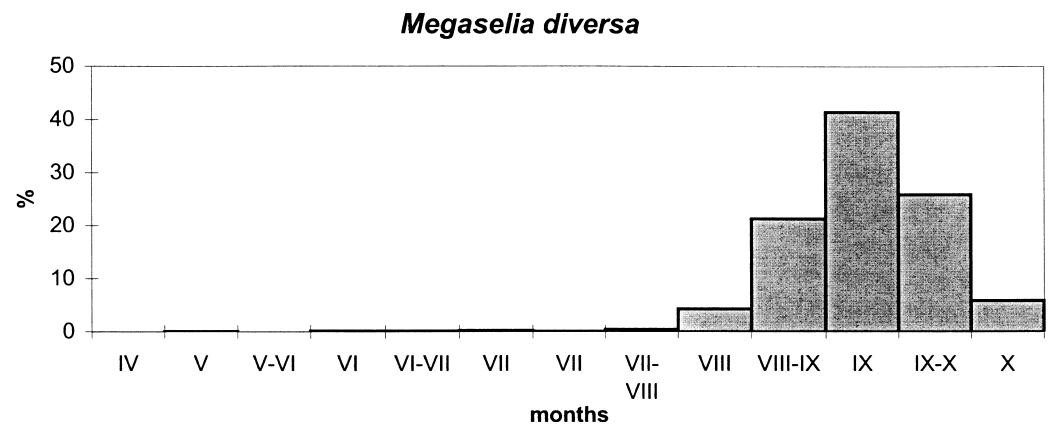

occurred in June. The autumn peak, which was three times higher than the spring peak, appeared in September (Fig. 1). The abundance of $M$. verralli remained very high until the end of October.

The first peak of Megaselia brevicostalis occurred at the turn of April and May. In autumn, the abundance of this saprophagous species remained high from August to October (Fig. 2).

Megaselia diversa (Wood) $(15.1 \%$ of the total catch), $M$. woodi (Lundbeck) $(14.8 \%)$ and $M$. giraudii (Egger) (12.7\%) were eudominant and dominant species in the young-growth phase stands. The abundances of $M$. brevicostalis and of $M$. verralli were low $(0.4 \%$ and $0.5 \%$, respectively) in these habitats.

$M$. giraudii $(25.2 \%$ of the total catch) and $M$. woodi $(13.2 \%)$ were the eudominant and dominant species of the large-pole timber phase stands. However, these two species co-dominated (about $25 \%$ each) the catches in the old-growth phase stands, too.

Megaselia diversa, the eudominant species in the young-growth phase, was collected as early as May, yet in small numbers. No clear abundance peaks were recorded either in spring or in sum- mer, but there was a very distinct peak in September (almost 45\%) (Fig.3).

The first individuals of Megaselia giraudii were collected at the turn of April and May. The first abundance peak occurred at the turn of June and July. In September, a rapid increase in the abundance was followed by a (less rapid) decrease (Fig. 4). The abundance of this polyphagous, dominant species was 20 times higher in the older stands than in the pine plantations.

The first individuals of Megaselia woodi were collected at the turn of August and September. Only in the large-pole timber stands did a few $M$. woodi emerge as early as June. The highest increase in the abundance of this species was in September (up to about 35\%; Fig.5). In the older stand-age classes, the abundance of $M$. wood $i$ was much higher than that in the pine plantations, and remained very high until the end of October. For this species a rapid increase in the abundance, followed by a decrease, was recorded in September in the large-pole timber and old-growth stands. $M$. woodi appeared in pine plantations in September. Its abundance increased gradually, reaching a peak at the end of October.

The phenologies of Megaselia brevicostalis, 

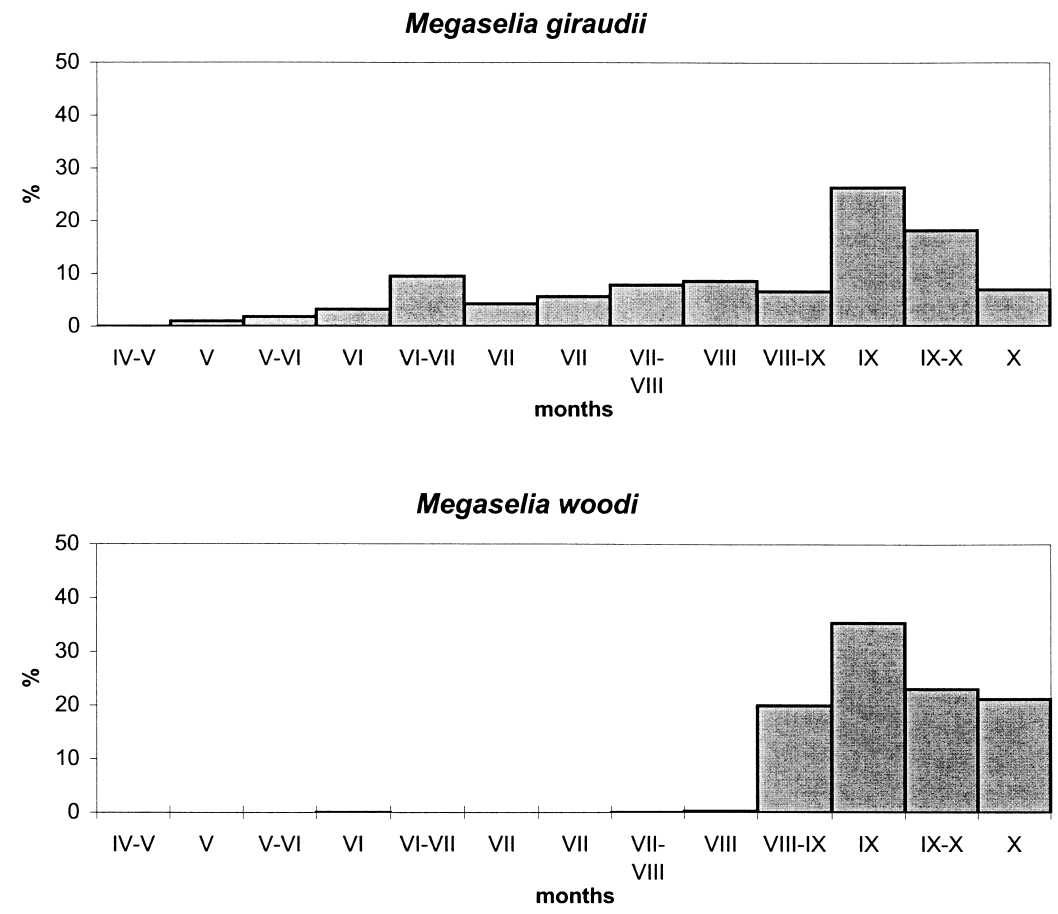

Fig. 4. The phenology of Megaselia giraudii in moist pine stands in the Białowieża Forest (age classes combined).
$M$. giraudii and $M$. verralli, the dominant species of moist pine forests, were characterized by two (or more; $M$. giraudii) abundance peaks, which indicate a multivoltine life cycle. The developmental biology of $M$. diversa, an autumn eudominant of the young-growth stands, is unknown, as is that of Megaselia woodi, the autumn dominant and eudominant of the older age classes, too. Both are univoltine. The abundance peaks of these two species were in September (Figs. 1-5).

Along an increasing age of a pine stand, distinct successional changes of phorid communities were recorded. Plantations were colonized by several (especially Megaselia) species. Megaselia species, especially $M$. verralli, $M$. brevicostalis, and also $M$. nigriceps, $M$. zonata, M. minor, Metopina oligoneura and Conicera dauci, dominate the catches in open sites. In the oldest age classes, these species are replaced by forest species of the genus Megaselia: $M$. diversa, $M$. woodi and $M$. giraudii and, among others, $M$. unicolor and M. pulicaria -complex, and also Phora penicillata. $M$. woodi and $M$. giraudii were the eudominant and the dominant phorid species of the oldest age classes, as earlier suggested by Durska (2001).

\section{Discussion}

The compositions of the phorid communities differ markedly between pine plantations and older stands. This difference reflects the increasing shadiness, caused by the growth of young trees. Photophilous open-habitat species are replaced by forest species that are better adapted to new conditions. Increasing shadiness drastically reduces the abundance of the early colonizers (Horn 1974, Durska 2001).

It was found that within the phorid communities of pine forest, species of the genera Phora, Megaselia, Anevrina, Borophaga and Conicera had their highest abundances in the earliest abundance peak (in May). Moreover, Phora species were the most abundant, being more than twice as numerous in the samples as Megaselia species. Metopina and Triphleba species reached their spring-abundance peaks earlier, at the turn of April and May.

The second and later abundance peaks of particular species occurred at different times. For example, Anevrina peaked in July, Borophaga peaked in July and September, Conicera peaked at the turn of June and July but also in August, 
and Megaselia was abundant at the turn of June and July but had its highest abundance in September. Moreover, Metopina peaked in July and September, Phora peaked in August, and Triphleba peaked at the turn of August and September. The highest abundance peak of the genus Phalacrotophora was recorded at the turn of June and July, being connected with the biology of the host (coccinellids) (Durska 2001).

In the phorid community of the pine plantation, the abundance of saprophagous species reached almost $90 \%$ of the total catch. Of these, the most abundant was bivoltine Megaselia brevicostalis. Prescher (1992) and Buck (1997) also observed that $M$. brevicostalis dominated open sites. In an agricultural ecosystem, Prescher (1992) observed only one abundance peak (in August) for this species. The first individuals of $M$. brevicostalis were collected in June.

In the scuttle-fly communities of the older ageclass stands, polyphagous species were the most abundant, representing approximately $60 \%$ of the total catch of the young-growth stands, and approximately $73 \%$ of the large-pole timber and oldgrowth stands. Of the polyphagous phorids, $M$. giraudii, being dominant and ubiquitous, was the most abundant species.

Within the phorid communities, the phenology of some species is completely different from that of the five dominant species of Megaselia. Some Triphleba species, for example, occur only during the cold season (e.g. T. autumnalis, T. trinervis) (Buck 1997, Durska \& Soszyńska in prep.). Some phorid species are the most abundant in spring, e.g. Anevrina curvinervis and Spiniphora maculata, and some species occur year-round, e.g. certain species of the Megaselia pulicaria group (Buck 1997, Durska 2001).

Acknowledgements. I thank especially Dr. R. Henry L. Disney for his kind help. I am grateful to Dr. Matthias Buck for his comments on an earlier version of the manuscript. This work was funded by the Komitet Badań Naukowych, PAN (Committee for Scientific Research, PAS).

\section{References}

Bańkowska, R. \& Garbarczyk, H. 1982: Charakterystyka terenów badań oraz metod zbierania i opracowywania materiałów. - In: Zoocenologiczne podstawy kształtowania środowiska przyrodniczego osiedla mieszkaniowego Białołęka Dworska w Warszawie. Część I. Skład gatunkowy i struktura fauny terenu projektowanego osiedla mieszkaniowego. Fragm. Faun. 26 (1981): 17-26.

Buck, M. 1997: Untersuchungen zur ökologischen Einnischung saprophager Dipteren unter besonderer Berücksichtigung der Phoridae und Sphaeroceridae (Brachycera/ Cyclorrhapha). —-Ph.D. thesis, Universität Ulm, Germany.

Disney R. H. L. 1994: Scuttle flies: The Phoridae. Chapman \& Hall, London, 467 pp.

Disney, R. H. L., Coluson, J. C. \& Butterfield, J. 1981: A survey of the scuttle flies (Diptera: Phoridae) of upland habitats in Northern England. — Naturalist 106: 53-66.

Durska, E. 1996: The species composition and structure of scuttle fly communities (Diptera: Phoridae) in mature tree stands in pine forests at different stages of habitat degradation. - Fragm. Faun. 39: 267-285.

Durska, E. 2001: Secondary succession of scuttle fly (Diptera: Phoridae) communities in moist pine forest in Białowieża Forest. — Fragm. Faun. 47: 81-130

Horn, H. S. 1974: The ecology of secondary succession. Annu. Rev. Ecol. Syst. 5: 25-37.

Matuszkiewicz, J., Degórski, M. \& Kozłowska, A. 1993: Description of the plant association structure and soils of pine forest stands situated in five regions of Poland. — In: Species composition and structure of pine forests fauna in Poland. Part I. Fragm. Faun. 36: 13-36.

Moericke, V. 1950: Über den Farbensinn der Pfirsichblattlaus Myzodes persicae Sultz. —Z. Tierpsychol. 7: 265-274.

Prescher, S. 1992: Ökologie und Biologie der Diptera, insbesondere der Brachycera, eines klärschlammgedüngten Ackerbodens. - Ph.D. thesis, University of Carolo-Wilhelmina zu Braunschweig, Germany.

Szujecki A. 1980: Ekologia owadów leśnych. - PWN, Warszawa, 603 pp. 